\title{
CROATIAN PUBLIC NOTARIES UNDER EUROPEAN CIVIL PROCEDURE LAW. A COMMENTARY ON THE JUDGMENT OF THE COURT OF JUSTICE OF THE EUROPEAN UNION (SECOND CHAMBER) MARCH 9, 2017, CASE C-551/15 - PULA PARKING $^{*}$
}

\author{
NOTARIOS PÚBLICOS CROATAS BAJO EL DERECHO \\ PROCESAL CIVIL EUROPEO.UN COMENTARIO SOBRE LA \\ SENTENCIA DEL TRIBUNAL DE JUSTICIA DE LA UNIÓN \\ EUROPEA (SALA SEGUNDA) 9 DE MARZO DE 2017, ASUNTO \\ C-551/15 - PULA PARKING*
}

\author{
LUCIENNE SCHLÜRMANN \\ Institute for comparative law, conflict of laws and international business law \\ University of Heidelberg, Germany
}

Recibido: 15.07.2018 / Aceptado: 26.07.2018

DOI: https://doi.org/10.20318/cdt.2018.4415

\begin{abstract}
The decision "Pula Parking", rendered by the European Court of Justice (ECJ) on March 9,2017 , deals with the recovery and enforcement of an unpaid debt resulting from the use of a public parking space. The main issue of the case is the question whether a Croatian notary, who is authorized under Croatian law to issue a writ of execution, qualifies as a "court or tribunal" responsible for "decisions or judgments" within the meaning of Regulation No 1215/2012 on jurisdiction and the recognition and enforcement of judgments in civil and commercial matters ${ }^{* *}$. In the past, the ECJ has never addressed this particular issue concerning the interpretation of the Regulation. Consequently, the ruling will serve as a landmark decision for future cases.

Keywords: Brussels I bis Regulation, "civil and commercial matters", term "court", Croatian public notary.

Resumen: La decisión "Estacionamiento de Pula", presentada por el Tribunal de Justicia de las Comunidades Europeas (TJUE) el 9 de marzo de 2017, trata de la recuperación y el cumplimiento de una deuda pendiente de pago derivada del uso de un estacionamiento público. La cuestión principal del caso es la cuestión de si un notario croata, autorizado por la legislación croata a emitir un mandamiento de ejecución, califica como un órgano jurisdiccional responsable de "decisiones o sentencias" en el sentido del Reglamento no 1215 / 2012 sobre jurisdicción y reconocimiento y ejecución de resoluciones judiciales en materia civil y mercantil **. En el pasado, el TJCE nunca se ha ocupado de esta cuestión particular relacionada con la interpretación del Reglamento. En consecuencia, el fallo servirá como una decisión histórica para casos futuros.
\end{abstract}

\footnotetext{
${ }^{*}$ European Court of Justice (ECJ) March 9, 2017, Pula Parking, 551/15, ECLI:EU:C:2017:193.

${ }^{* *}$ Regulation No 1215/2012 of the Europe Parliament and of the Council of 12 December 2012 on jurisdiction and the recognition and enforcement of judgments in civil and commercial matters, OJ 2012 L 351, 1.
} 
Palabras clave: Reglamento Bruselas I bis, materia civil y mercantile, término "tribunal", notario público croata.

Summary: I. The facts of the case and their legal background. II. Preliminary Questions. III. The solution of the European Court of Justice. 1. The applicability ratione temporis. 2. The application of Article 1 of Regulation No 1215/2012 to publicly owned companies. 3. The application of Regulation No 1215/2012 to Croatian public notaries. IV. Review. 1. Admissibility of the second preliminary question. 2. Autonomous interpretation of "courts": a methodical approach. 3. Coherence in European Private International Law instruments?. V. Conclusion.

\section{The facts of the case and their legal background}

1. Pula Parking d.o.o. is a company owned by the town of Pula in Croatia, which has been authorised through an administrative act to collect parking fees for the use of public parking spaces in the city. In September 2010, Sven Klaus Tederahn, a German resident at the time, parked his car in one of these public parking spaces. However, Mr Tederahn failed to pay both the parking fee and the parking ticket issued by Pula Parking within the required time frame. Therefore, Pula Parking lodged an application for enforcement with a Croatian public notary in Pula in February 2015.

2. Article 278 of the Croatian Enforcement Act (CEA) confers jurisdiction on public notaries to examine applications of enforcement that are based on "authentic instruments". Under Croatian law, an invoice or extract from accounting records or any other document considered to be official qualifies as an "authentic document". ${ }^{1}$ Here, Pula Parking referred to extracts of its accounting records which proved that Mr Tederahn owed approximately 13 euros for using the public parking area in 2010, including a late payment fee. These documents constitute "authentic documents" and made a procedure under Article 278 CEA admissible. Therefore, the Croatian notary issued a writ of execution on March 25, 2015.

3. Because Mr Tederahn lodged an opposition to that writ according to Article 282 (3) CEA, the case was transferred to the Municipal Court of Pula on April 21, 2015. Article 282 (3) CEA authorizes an appellate procedure and assigns jurisdiction to a court in case of an opposition to a writ based on Article 278 CEA. ${ }^{2}$ In his opposition, Mr Tederahn argued that the Croatian public notary, who issued the writ of execution, did not have substantive or territorial jurisdiction because of his habitual residence in Germany. This argumentation is supported by Croatian Law: Under the CEA, jurisdiction is given to a notary with an office in the territorial area of the residence or registered office of the defendant in the enforcement proceedings. Applications for enforcement made before a notary who does not have territorial jurisdiction will be dismissed by the court. ${ }^{3}$

\section{Preliminary Questions}

4. To settle the issue of territorial jurisdiction of a Croatian notary public, the Municipal Court of Pula decided to ask the ECJ for a preliminary ruling under Article 267 TFEU. The Court raised two questions:

The first question concerns the scope of Regulation No 1215/2012 and asks whether the legal nature of a party (here the public ownership of the Pula Parking company) has an impact on the applicability of the Regulation as it only applies to "civil and commercial matters" (cf. Art. 1 of the Regulation

\footnotetext{
1 See Art. 31 CEA, J. GARAŠIĆ also speaks of "trustworthy" documents, J. GarašIĆ in Introduction to the Law of Croatia, edited by Tatjana Josipović, Wolters Kluwer, The Netherlands, 2014, § 13.03 [B].

2 See the provisions meaning explained in ECJ March 9, 2017, Pula Parking, 551/15, ECLI:EU:C:2017:193, para 12.

3 ECJ March 9, 2017, Pula Parking, 551/15, ECLI:EU:C:2017:193, para 11.
} 
No 1215/2012). The second and more important question deals with the issue whether a Croatian public notary falls under the term "court" or "tribunal" within the scope of Regulation No. 1215/2012 which applies to "judgments" or "decisions" rendered by "courts or tribunals" (see Article 2 lit. a)).

\section{The solution of the European Court of Justice}

5. Overall, one can agree with the answers of the European Court of Justice to the questions above that will be presented in the following paragraphs. After a brief summary of the main arguments (part III), the Court's reasoning will lead to some general observations about the Court's methods when interpreting Regulation No 1215/2012 (part IV).

\section{The applicability ratione temporis}

6. Mr Tederahn had pleaded before the ECJ that the Regulation No 1215/2012 was inapplicable $r a$ tione temporis because the Republic of Croatia joined the European Union not until July 1, 2013, whereas the parking contract had already been formed in 2010. Thus, the judgment of the ECJ starts with a short statement on the temporal scope of Regulation No 1215/2012. According to Article 66 (1) the Regulation applies to all legal proceedings instituted on or after January 10, 2015. In this case, the enforcement proceedings before the public notary commenced in February 2015 and were referred to the Pula Municipal Court on April 21, 2015. Therefore, the whole enforcement procedure falls under the temporal scope of Regulation No 1215/2012. According to the opinion of Advocate General (AG) Bobek and the Court's final decision, the conclusion of the contract has no influence on the temporal applicability of the Regulation. Instead, Art. 66 (1) refers to the starting point of the proceedings, and thereby reflects a fundamental principle of intertemporal civil procedure law. ${ }^{4}$ Thus, substantive aspects of the case cannot be taken into account.

\section{The application of Article 1 of Regulation No 1215/2012 to publicly owned companies}

7. With its first question, the Pula Municipal Court raises the issue whether a contract formed between a natural person and a publicly owned company can be treated as a "civil or commercial matter" within the meaning of Article 1 of Regulation No 1215/2012.

8. As a first step, the Court confirms the principle of continuity as a method of interpretation of the (repealed) Regulation No 44/2001 and Regulation No 1215/2012. Both sets of rules use the terms civil and commercial matters in their respective Article 1 and, therefore, must be interpreted in a uniform way. ${ }^{5}$ Next, the Court states that "civil and commercial matters" are an autonomous concept that must be interpreted in light of the objectives of the Regulation and the general principles that originate from the foundation of the national legal systems. ${ }^{6}$

9. Starting from these general premises, the Court then refers to its wide case law on the term of "civil and commercial matters": In the past, the Court had found that the nature of the legal relationship between the parties is decisive. ${ }^{7}$ The decision points to three factors to determine the legal relationship in the present case: First of all, one has to determine the different interests pursued in such a relationship. The management and maintenance of a public parking space is a task carried out with a public interest.

\footnotetext{
${ }^{4}$ P.F.Schlosser/B.Hess, EU-Zivilprozessrecht, $4^{\text {th }}$ ed., C.H. Beck, Munich, 2015, EuGVVO, Art. 66 para 2; P.MANKOwKSI in: U.Magnus (ED.), European Commentaries on private international law, Brussels Ibis Regulation, Cologne, Otto Schmidt, 2016, Art. 66 para 4.

5 ECJ March 9, 2017, Pula Parking, 551/15, ECLI:EU:C:2017:193, para 31.

${ }^{6}$ ECJ March 9, 2017, Pula Parking, 551/15, ECLI:EU:C:2017:193, para 33.

7 ECJ March 9, 2017, Pula Parking, 551/15, ECLI:EU:C:2017:193, para 34 with references to the previous judgments of April 11, 2013, Sapir and Others, 645/11, ECLI:EU:C:2013:228, para 34 and September 12, 2013, Sunico and Others, 49/12, ECLI:EU:C:2013:545, para 35.
} 
In contrast, the agreement between the parties as well as the enforcement of the claim constitute a purely private interest. 8 Offering parking spaces for individuals does not require any public authority. The involvement of the public authority in this case is limited to the empowerment of the Pula Parking company by the mayor and does not include any authorisation for a compulsory execution. Even if the Court insists on its autonomous interpretation, this argumentation resembles the German Interessentheorie (interest theory) that is used in German public law to separate public and private actions of public authorities. ${ }^{9}$

10. In the following, in a second and third step, the Court analyzes the character of the debt and the legal consequences resulting from the missing payment of it: Here, the contract neither imposes any penalties nor - even more importantly - gives any power of self-enforcement to the Pula Parking company. Therefore, the Court concludes that the parking fee has a purely private character and lacks any punitive element indicating public influence. Consequently, the facts are covered by Article 1 of Regulation No 1215/2012.10

\section{The application of Regulation No 1215/2012 to Croatian public notaries}

11. The main issue of the case is the question whether a Croatian public notary involved in the enforcement proceeding of an "authentic document" falls within the scope of Regulation No 1215/2012.

As a first step, the Court clarifies again that the concept of a "court" within Regulation No $1215 / 2012$ must be based on an autonomous definition of the term and must take into account the objectives, the overall structure and the origin of the Regulation. ${ }^{11}$ Considering the fact that the terms "court" or "tribunal" are used several times in the Regulation without any definition of the term itself, one can only refer to the general provisions in Articles 1, 2 and 3 of the Regulation.

12. In the following, the argumentation of the Court appears to be systematic at first sight: ${ }^{12}$ The ECJ states that Article 3 of Regulation No 1215/2012 explicitly includes Swedish and Hungarian authorities that are not considered to be part of the judiciary. This indicates that other public authorities not mentioned in this Article do not fall within the scope of the Regulation (argumentum e contrario). Consequently, the Court rejects a wide interpretation of the term "court" as proposed by the city of Pula and the Croatian government. ${ }^{13}$

Within the systematic analysis, the Court also discusses a functional approach laid down in Article 3 (2) of Regulation No 650/2012 14 : The provision explicitly encompasses not only judicial authorities but any authority exercising judicial functions. However, the ECJ rejects the parallel interpretation because Regulation No 1215/2012 does not contain such provisions. ${ }^{15}$

13. In support of its strictly systematic approach to interpret the term "court" autonomously, the ECJ then refers to the "well-established" principles of mutual recognition of judicial and extra-judicial decisions in civil matters (cf. Article 67(4) TFEU) that guarantee rapid and simple access to justice in the EU as an area of freedom, security and justice. ${ }^{16}$

The Court believes that the principles of mutual trust and recognition play a fundamental role in EU law and will gain more and more importance, especially in the area of European Civil Procedure

\footnotetext{
8 ECJ March 9, 2017, Pula Parking, 551/15, ECLI:EU:C:2017:193, para 35.

9 Similar H.Rотн, "Vollstreckungsbefehle kroatischer Notare und der Begriff „Gericht" in der EuGVVO und der EuVTTVO", Praxis des internationalen Privat- und Verfahrensrechts (IPRax) 2018, 41.

${ }_{10}$ ECJ March 9, 2017, Pula Parking, 551/15, ECLI:EU:C:2017:193, para 36 and 37.

11 ECJ March 9, 2017, Pula Parking, 551/15, ECLI:EU:C:2017:193, para 42.

12 For a different interpretation see infra part V.

13 ECJ March 9, 2017, Pula Parking, 551/15, ECLI:EU:C:2017:193, para 41 and 46.

14 Regulation (EU) No 650/2012 of the European Parliament and of the Council of 4 July 2012 on jurisdiction, applicable law, recognition and enforcement of decisions and acceptance and enforcement of authentic instruments in matters of succession and on the creation of a European Certificate of Succession.

15 ECJ March 9, 2017, Pula Parking, 551/15, ECLI:EU:C:2017:193, para 47 and 48.

16 See para 53 of the cited decision and the recitals 3 and 4 of Regulation No 1215/2012.
} 
Law. ${ }^{17}$ At the same time, however, the Court takes on a rather practical perspective towards these aims in the content of Regulation No 1215/2012: The application of the principle of mutual trust by courts of the Member States requires a simple and a comprehensible way to identify foreign judgments that fall within the scope of the Regulation. Nevertheless, this "apparent" simplicity seems to encounter some difficulties in cases similar to the present one where the responsible authority has some kind of "split" competence.

14. Moreover, according to the ECJ's reasoning, the principle of mutual trust in jurisdictional decision requires a guaranteed minimum of independence and impartiality as well as compliance with the principle of audi alteram partem. ${ }^{18}$ When applying this analysis to the present case, the Court finds that the procedure before a Croatian public notary does not comply with the principle of audi alteram partes, due to the absence of any prior notice of the writ of execution to the debtor. ${ }^{19}$ The Court argues that this reasoning is strengthened by the fact that notaries and courts in Croatia are generally part of two strictly separated systems. ${ }^{20}$

\section{Review}

15. The Court's analysis and response to the first preliminary question on the applicability of Regulation No 1215/2012 to a dispute between a natural person and a publicly owned company appears to be accurate. The separation of public and private law in cases concerning public authorities forming private contracts must be decided on a case-by-case basis. The criteria mentioned in the present case safeguard the guidelines the Court has developed in the past to interpret Article 1 of Regulation No $1215 / 2012$. Because of the multiple possibilities public authorities have to interact with private individuals, it does not seem beneficial to develop one definite rule. Instead, a variety of precise and feasible criteria has the most value for the Member States when interpreting the Regulation.

16. Similarly, one can agree with the result of the second question although its foundation seems to be rather insufficient and fragmentary. To explain this point of view in more detail, the following section will first analyse the admissibility of the preliminary question - an issue mentioned only briefly in the Opinion of the Advocate General Bobek ${ }^{21}$ but not at all discussed in the judgment. The following two paragraphs will then focus on the method of autonomous interpretation used by the Court.

\section{Admissibility of the second preliminary question}

17. Admissibility under Article 267 TFEU requires relevance of the matter in dispute for the pending proceeding of the referring Member State court. Thus, the question must be essential to render a decision. ${ }^{22}$ In the present case, one may doubt the admissibility of the second preliminary question: ${ }^{23}$ The moment where, under Croatian law, the notary is forced to transfer the case to the municipal court (cf. Art. 282 (3) of the CEA), the case "enters" the judicial system. Every decision taken by the Croatian court, no matter the outcome, will be a decision by a "court" within the meaning of Regulation No 1215/2012. Unfortunately, the Municipal Court did not explain the reasons leading him to request a preliminary ruling. Nevertheless, one must take into account the following consideration: If the municipal court rejects the opposition for lack of jurisdiction, this reasoning will not be justified without examining

17 ECJ March 9, 2017, Pula Parking, 551/15, ECLI:EU:C:2017:193, para 51 (with further references).

18 ECJ March 9, 2017, Pula Parking, 551/15, ECLI:EU:C:2017:193, para 54, 55.

19 ECJ March 9, 2017, Pula Parking, 551/15, ECLI:EU:C:2017:193, para 58.

20 ECJ March 9, 2017, Pula Parking, 551/15, ECLI:EU:C:2017:193, para 56.

21 Advocate General M. Bobek, Opinion of October 27, 2016, Pula Parking, 551/15, ECLI:EU:C:2016:825.

${ }^{22}$ U.Magnus in U.Magnus (ED.), European Commentaries on private international law, Brussels Ibis Regulation, Cologne, Otto Schmidt, 2016, Introduction, para 121.

23 Advocate General M. Bobek, Opinion of October 27, 2016, Pula Parking, 551/15, ECLI:EU:C:2016:825, as well as J.Wolber, "Der Begriff des "Gerichts" im Europäischen Zivilprozessrecht am Beispiel kroatischer Notare", Europäische Zeitschrift für Wirtschaftsrecht (EuZW) 2017, 680, 683. 
whether the Croatian public notary had rightfully determined his territorial jurisdiction. For this analysis, however, it is important to know whether the notary is obligated to apply Regulation No 1215/2012.

18. In view of this reasoning, one must agree with the line of argumentation presented by AG Bobek in his opinion: ${ }^{24}$ For AG Bobeck, Article 267 TFEU includes a large presumption of relevance that cannot be completely rebutted in this case; the evaluation of this relevance is incumbent upon the Member State courts. ${ }^{25}$ This cautious attitude towards the evaluation of relevance within the meaning of Article 267 TFEU is traditional for the ECJ case law. ${ }^{26}$ In addition, the present case shows that a broadly understood presumption and a lenient position of the Court in case of missing or inadequate explanations concerning the relevance by the referring court may lead to a landmark decision that will simplify the application of the EU Private International Law instruments. This outcome seems to be based on political desire rather than on legally founded reasons.

\section{Autonomous interpretation of "courts": a methodical approach}

19. In addition, the judgment in Pula Parking shows some interesting approaches to the general method of reasoning in the ECJ's latest case-law:

As we have seen above (see supra IV.3.), the Court takes on a rather "systematic" approach towards the issues of the case. At first sight, it seems as if the Court explicitly rejects a "functional" approach as used in the interpretation of Art. 3 (2) of Regulation No 650/2012. ${ }^{27}$ The reference to the separation of courts and notaries in the Croatian judicial systems points to an "institutional" definition of the term "court". ${ }^{28}$ However, this approach is not convincing: the core issues for the analysis are the similar (or different) tasks and functions as well as the similar (or eventually different) procedures of the two authorities, not in their classification within the judicial system. The subsequent reasoning is even less persuasive: The approach especially considers detailed characteristics of Member States' legal systems which completely contradicts the widely quoted autonomous interpretation of the European Private International Law, a method explicitly outlined by the Court in the beginning of the judgment. ${ }^{29}$

20. Nevertheless, one can argue that the Court uses a certain kind of "functional" approach in its argumentation. As discussed above, the decisive factor is the different procedural settings in a court room and before a public notary, especially regarding the rights of the parties. The principle of audi alteram partes is a fundamental principle that guarantees an equal process and the independence of the deciding authority. ${ }^{30}$ Therefore, the Croatian courts and notaries seem to differ more with regard to the procedure and their judicial competences than to their institutional structure. Consequently, because these differences originate from different tasks of the authorities and, therefore, from the function they perform in a specific legal system, the Court ultimately uses a functional approach to justify its considerations.

21. As a result, the Court's approach appears to resemble General Advocate Bobek's proposal of a "two-part definition" of the term "court": $:$ In a first step, Bobek proposes an institutional definition

${ }^{24}$ Advocate General M. Bobek, Opinion of October 27, 2016, Pula Parking, 551/15, ECLI:EU:C:2016:825, para 37, 59 and 61 .

25 Advocate General M. Bobek, Opinion of October 27, 2016, Pula Parking, 551/15, ECLI:EU:C:2016:825, para 60.

26 B.W.Wegener, in C.CAllies/M.Ruffert (ed.), EUV/AEUV, 5 $5^{\text {th }}$ ed., Munich, C.H.Beck, 2016, Art. 267 para 22 ff.

27 See also H. Rотн, "Vollstreckungsbefehle kroatischer Notare und der Begriff „Gericht" in der EuGVVO und der EuVTTVO“, Praxis des internationalen Privat- und Verfahrensrechts (IPRax) 2018, 41, 43; J. WolbeR, "Der Begriff des "Gerichts" im Europäischen Zivilprozessrecht am Beispiel kroatischer Notare", Europäische Zeitschrift für Wirtschaftsrecht (EuZW) 2017, 680, 683.

${ }_{28}$ H. Rотн, "Vollstreckungsbefehle kroatischer Notare und der Begriff „Gericht" in der EuGVVO und der EuVTTVO“, Praxis des internationalen Privat- und Verfahrensrechts (IPRax) 2018, 41, 43.

29 See ECJ March 9, 2017, Pula Parking, 551/15, ECLI:EU:C:2017:193, para 33.

30 This principle is namely based on Article 6 ECHR, cf. H.LinKE/W.HAU, Internationales Zivilverfahrensrecht, $6^{\text {th }}$ ed., Cologne, Otto Schmidt, 2015, chapter 3, para 3.48.

31 Proposing another approach H. Rотн, "Vollstreckungsbefehle kroatischer Notare und der Begriff „Gericht“ in der EuGVVO und der EuVTTVO“, Praxis des internationalen Privat- und Verfahrensrechts (IPRax) 2018, 41, 43. 
with reference to the judicial structures of the Member States that is then completed, in a second step, by a functional definition to correct potential mistakes. ${ }^{32}$ Therefore, the ECJ's reasoning seems to be close to this approach. However, one must conclude, that unfortunately, the Court uses no clear method or sustainable criterion besides the well-known keywords of mutual recognition and trust. ${ }^{33}$

\section{Coherence in European Private International Law instruments?}

22. The line of argumentation does not give a clear reason why the Court rejects a functional method in the present case, especially since it contradicts the approach used in Regulation No 650/2012. One explanation could be the fact that there is a difference between the "isolated" codification of the European Civil Procedural Law in Regulation No 1215/2012 and the Regulation No 650/2012 which contains both, jurisdiction and conflict of laws provisions. Yet, such a technicality should not be crucial for deciding on a method of interpretation of different European Law instruments. Another indication is the fact that most of the "contemporary" EU Private International Law instruments contain provisions in both areas. ${ }^{34}$ To conclude, one has to mourn once again a lost opportunity for the ECJ to define the term of autonomous interpretation and to clarify the relationship between the numerous procedural instruments in European Private International Law.

\section{Conclusion}

23. The decision of the ECJ in the case Pula Parking shows that even several years after its implementation, the scope of Regulation No 1215/2012 is still unclear and leaves open many questions. Because of the still existing diversity in European legal and judicial systems, one can assume that new issues will arise in the future. The diversity of systems conflicts with the numerous instruments and methods in European Private International Law that were originally aimed at simplifying and harmonising access to justice in the European Member States. To advance this objective, the European Court of Justice must clarify its method of autonomous interpretation and at the same time provide content for well-known keywords such as "mutual trust and recognition". Furthermore, instead of posing as an objective, the term mutual trust and recognition should become a real "fundament" of the European area of freedom, safety and justice. The ECJ should shift towards a functional approach - potentially inspired by the functional method of comparative law - to ensure a coherent interpretation of European Private International Law. ${ }^{35}$

\footnotetext{
32 Advocate General M. Bobek, Opinion of October 27, 2016, Pula Parking, 551/15, ECLI:EU:C:2016:825, para 83.

33 J. Wolber, "Der Begriff des "Gerichts" im Europäischen Zivilprozessrecht am Beispiel kroatischer Notare", Europäische Zeitschrift für Wirtschaftsrecht (EuZW) 2017, 681, 683.

34 See the new Council Regulation (EU) 2016/1103 of 24 June 2016 implementing enhanced cooperation in the area of jurisdiction, applicable law and the recognition and enforcement of decisions in matters of matrimonial property regimes and Council Regulation (EU) 2016/1104 of 24 June 2016 implementing enhanced cooperation in the area of jurisdiction, applicable law and the recognition and enforcement of decisions in matters of the property consequences of registered partnerships entering into force on 29 January 2019.

35 The functional method of Comparative law was founded by KonRad ZweIGERT AND HeIN KöTz in their Introduction to Comparative Law, $2^{\text {nd }}$ ed., Oxford, Clarendon Press, 1992, pp 28.
} 